\title{
A bleaching event on a Brazilian coral reef
}

\author{
Clovis B. Castro \& Débora O. Pires \\ Museu Nacional da Universidade Federal do Rio de Janeiro \\ Departamento de Invertebrados \\ (Quinta da Boa Vista s/nº, 20940-040, Rio de Janeiro, RJ, Brasil)
}

\begin{abstract}
Brazil has the only coral reefs of the western
South Atlantic, which are scattered along approximately $2,000 \mathrm{~km}$. Many reef areas are still poorly known, but the Abrolhos area (approximately between latitudes $17^{\circ} 20^{\prime} \mathrm{S}$ and $18^{\circ} 10^{\prime} \mathrm{S}$ ), located on an expansion of the continental shelf, is considered to have the largest and richest reefs in the Atlantic Ocean south of the Amazon River (Laborel, 1970). All 15 species of stony reef corals recorded for Brazil
\end{abstract} occur in these reefs and five are endemic to Brazil.

In 1992, a coral-cover monitoring program was initiated at the Viçosa Reef - the southernmost reef of the Abrolhos area. The 13 zooxanthellate coral species of this reef were comprised by 12 scleractinians and the hydrozoan Millepora alcicornis, and reached a maximum cover of $23 \%$ average cover being approximately $6 \%$ (Castro \& Young, unpublished data). During this program, many bleached colonies were observed among the major reef corals. This paper reports a bleaching event in Brazil, and discusses the possible contribution of temperature variation on it.

Data were collected during summer (18-25 March 1993; 27 February-6 March 1994; 13-21 March 1995; 3-7 February 1996) and winter (26 September-2 October 1992; 15-21 August 1993; 19 25 August 1994; 24-30 August 1995). The percentage of bleached (total or partial) or pale corals in one station $\left(17^{\circ} 58.266 \mathrm{~S}, 039^{\circ} 15.371^{\prime} \mathrm{W}\right)$ was determined by the observation of colonies larger than $3 \mathrm{~cm}$ in diameter in areas of $100 \mathrm{~m}^{2}$ in the winter of 1993, and every field trip afterwards. Colonies up to $1 \mathrm{~m}$ away from both sides of a $50 \mathrm{~m}$ long leaded rope, extended along the reef border, at a depth of 2-3 m, were examined and counted. As the location of examined areas were not exactly the same, different numbers of colonies were examined in each trip. Species of Mussismilia (M. braziliensis, $M$. hispida and $M$. hartti) were used in the present study, as they usually ( 15 out of 18 times) presented more than 20 specimens in the observed areas. Bleached (pure white) and pale (light "whitish" cream) were counted together because there was a continuous variation in these colors and because they were readily distinguished from the usual colony colors (brown or green).

Weekly mean sea surface temperatures (SST) were obtained from the United States National Oceanographic and Atmospheric Administration (NOAA) (Reynolds \& Smith, 1994). Data from grid point centered on $17^{\circ} 30^{\prime} \mathrm{S}, 038^{\circ} 30^{\prime} \mathrm{W}$ were used. It includes most of the area's shallow platform ( $<20 \mathrm{~m}$ depth) where the reef complex lies. Anomalies in SST were detected by comparing the average temperature of 1982-1995 with the temperature curve of the specific year.

The data on the duration of daylight was based on sunrise and sunset hours in the studied area, calculated using the coordinates $17^{\circ} 30^{\prime} \mathrm{S}$, $038^{\circ} 30^{\prime} \mathrm{W}$. Data were averaged by week of the year to simplify graphical comparison with SST data.

In the winter of 1992 , bleaching was noted in Viçosa Reefs but not quantified. In the summer of 1993, other reefs were visited and unquantified bleaching was observed in colonies of several stony coral species on many reefs in the Abrolhos area (Parcel das Paredes or Paredes Reefs, Popa Verde, and Viçosa Reefs), as well as on a reef to the north of this area (Parcel do Pataxo, approximately $16^{\circ} 58^{\prime}$ 'S, $039^{\circ} 09^{\prime} \mathrm{W}$ ).

There was a sharp increase of bleached colonies of Mussismilia spp. from the winter of 1993 to the summer of 1994 (Fig. 1). This rise was followed by a decline in the winter of 1994, to an almost complete absence of bleaching (maximum $=$ $2.6 \%$ in $M$. braziliensis). Subsequently, colonies affected by bleaching in these species were fewer than $20 \%$ and, excluding $M$. hartti, these numbers would be at most $10 \%$. Nine species were recorded in the $100 \mathrm{~m}^{2}$ areas (Mussismilia spp. (3), Agaricia agaricites, Favia gravida, Montastrea cavernosa, Porites astreoides, P. branneri, and Siderastrea stellata). All recorded species presented bleached colonies several times, although the number of observed colonies was insufficient for an analysis of trends. 


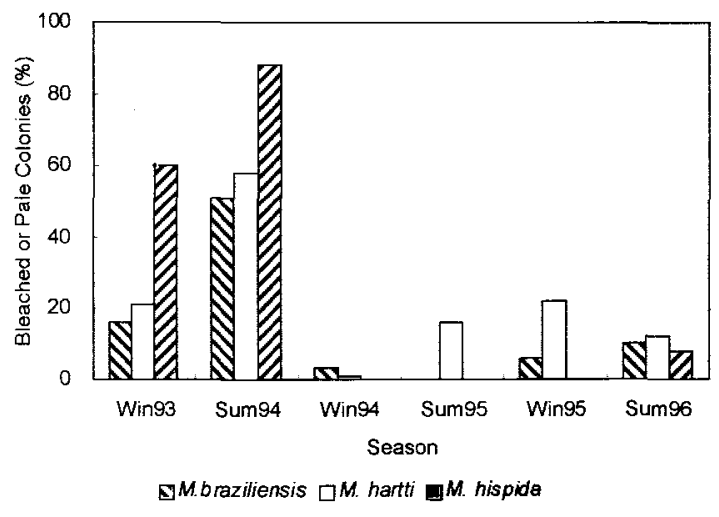

Fig. 1. Percentage bleaching in Mussismilia in Viçosa Reef, Abrolhos, Brazil, based on counting colonies in quadrats of $100 \mathrm{~m}^{2}$.

Win $=$ winter; Sum $=$ summer.

The available data on bleaching, although limited, clearly showed the occurrence of a major event in 1994. The climax of this event seems to have occurred in the summer of that year. Another bleaching event in Brazil was reported for this latter period in a non-coral reef area at São Paulo State (Migotto, 1997). Migotto associated the bleaching event with abnormally high water temperatures.
The SST data for the Abrolhos Area showed two strong departures from the average annual temperature curve in 1992 and 1994 (Fig. 2). In 1992, the summer season showed temperature peaks later in the year, while in 1994 they occurred almost a month before usual. In both cases, maximum temperatures were similar to average yearly maxima. However, due to the timing of the peak, more than a month after (1992) or before usual (1994), the curves stayed well below (1992) or above (1994) the average curve. A similar situation was found by Hagman \& Gittings (1992) in a bleaching in the Gulf of Mexico. They observed only minor bleaching ( $<10 \%$ of all colonies), but this may be due to observations at depths greater than $20 \mathrm{~m}$.

In the current study, there was a high SST anomaly in the summer of 1994, although with temperatures within "normal" yearly maxima. For some authors, this would be sufficient to cause bleaching (Goreau \& Hayes, 1994). It has also been suggested that solar radiation can act in synergy with temperature to cause bleaching (Glynn et al., 1992). Peaks of duration of daylight and SST occurred very close to each other in 1994 in the Abrolhos area (Fig. 2). The synergy of these peaks and temperature anomaly could explain why there

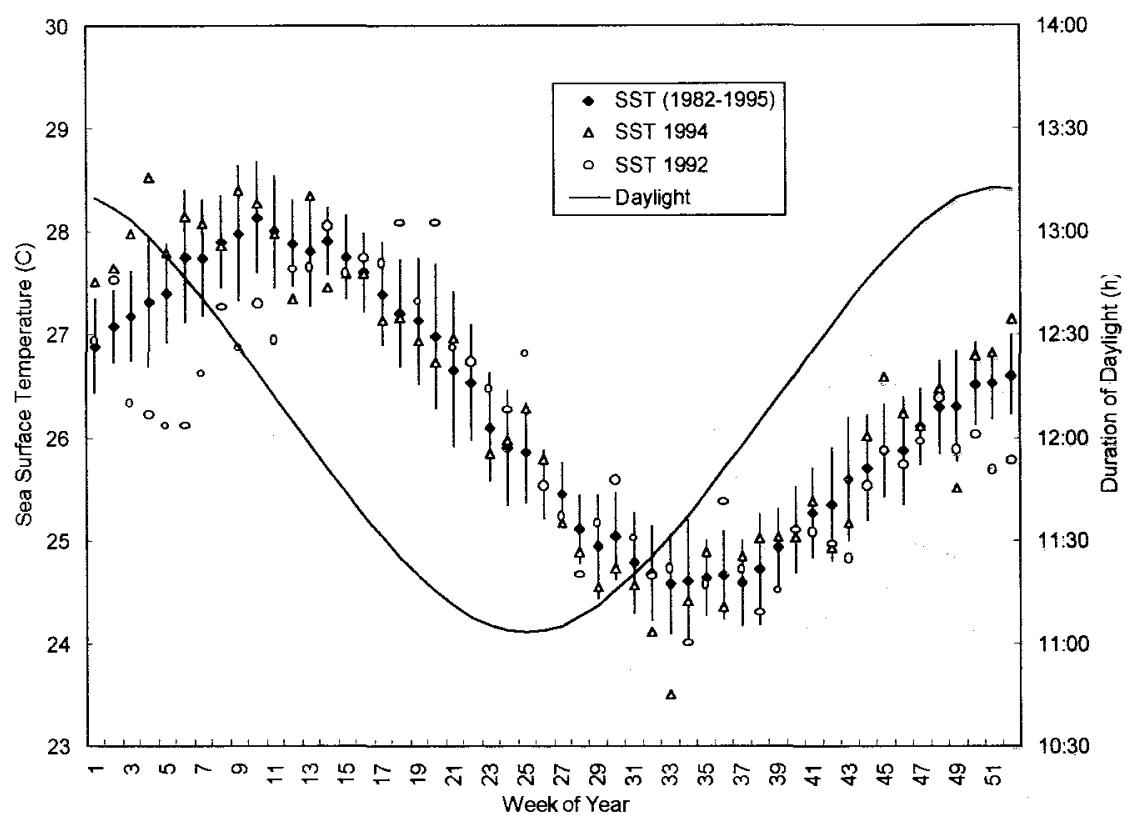

Fig. 2. Sea surface temperature (SST) $\left({ }^{\circ} \mathrm{C}\right.$ ), based on a $1^{\circ}$ grid satellite data centered on $17^{\circ} 30^{\prime} \mathrm{S}$, $038^{\circ} 30^{\prime} \mathrm{W}$, and duration of daylight (in hours), calculated for the same coordinate, in the Abrolhos Reefs: a) weekly mean SST in 1994; b) weekly mean SST in 1992; c) average weekly mean SST from 1982 to 1995 (vertical bars indicate standard deviation); and d) duration of daylight in 1994, averaged by week. 
was bleaching in 1994, when similar temperatures did not cause it in other years. The use of daylight length to estimate solar radiation is supported by the results of Al-Sofyani \& Spencer Davies (1992).

Ware et al.'s (1996) model of the adaptive bleaching hypothesis (Buddemeier \& Fautin, 1993) predicted that a bleaching event associated with high temperatures might occur in two different situations: abnormally high temperatures, such as reported by Migotto (1997); and on a return to regular temperatures, following a few years of low temperatures. Bleaching without higher than longterm average temperatures was recorded in the Caribbean (Ware et al., op. cit.). Our data for 1993 and preceding years also conform to this - 1992 was an abnormally cool year, as was the winter of 1991 .

Unfortunately, bleaching was not quantified in the summer of 1993, when the return to regular summer temperatures was observed. It is not possible, therefore; to show if bleaching in that summer was an event of higher than average magnitude. Since bleaching often occurs in two consecutive years (Glynn, 1991), the uncounted event in the summer of 1993 may have been the first occurrence of a series, which was followed by the second (and stronger due to the long positive anomaly) in 1994.

On the other hand, the bleaching in the winter of 1992 may have been due to background bleaching (sensu Ware et al., op. cit.), which was also detected in field trips after the major event of 1994. According to Migotto (op. cit.), two-thirds of bleached colonies of Mussismilia hispida recovered normal color four months after they bleached. This would suggest that bleaching seen in the winter immediately after the main bleaching event could be due to unrecovered colonies, suggesting that new minor bleaching events occurred after the major bleaching of 1994 (Fig. 1). Similarly, minor events might also have occurred before.

The constant occurrence of background bleaching could be explained, in the case of the warm season, by the presence of competitively superior zooxanthellae in low temperatures that do not stand warm season temperatures. These algae would establish in corals during the cool season, but would bleach the following warm season (Ware et al., op. cit.). Other environmental stresses, mostly related to sedimentation, occur seasonally in Viçosa Reefs, with extreme conditions in the cool season (Leão et al., 1988). This may also cause bleaching in some corals and account for yearly (or episodic) winter bleaching, and interfere with the analysis of temperature-related bleaching. As the studied area is very shallow $(<3 \mathrm{~m})$, these stresses, with temperature and radiation, may present a strong influence in the bleaching events here reported.

\section{Acknowledgement}

We are indebted to: Dr. P. S. Young (Museu Nacional, Rio de Janeiro - MNRJ), Dr. R. Buddemeier (University of Kansas), and Dr. T. J. Goreau (Global Coral Reef Alliance), for access to discussions and papers; J. O. Nascimento (Observatório Nacional/CNPq), for data on sunrise and sunset hours; Dr. P. S. Young, C. C. Ratto, and C. A. Echeverría, for assistance in the field; Dr. R. W. Reynolds (NOAA), for help in obtaining SST data; Dr. J. C. Creed and G. W. Nunan (MNRJ), for help with the final English version; CNPq, FAPERJ, FUJB, and UFRJ, for grants to our Laboratory.

\section{Reférences}

Al-Sofyani, A. \& Spencer Davies, P. 1992. Seasonal variation in production and respiration of Red Sea corals. In: INTERNATIONAL CORAL REEF SYMPOSIUM, 7. Guam, 1992. Proceedings. Guam, 1:351-357.

Buddemeier, R. W. \& Fautin, D. G. 1993. Coral bleaching as an adaptive mechanism: a testable hypothesis. Bioscience, 43(5):320-326.

Glynn, P. W. 1991. Coral reef bleaching in the 1980 's and possible connections with global warming. Trends Ecol. Evolut., 6(6):175-179.

Glynn, P. W.; Imai, R.; Sakai, K.; Nakano, Y. \& Yamazato, K. 1992. Experimental responses of Okinawan (Ryukyu Islands, Japan) reef corals to high sea temperature and UV radiation. In: INTERNATIONAL CORAL REEF SYMPOSIUM, 7. Guam, 1992. Proceedings. Guam, 1:27-37.

Goreau, T. J. \& Hayes, R. L. 1994. Coral bleaching and ocean "Hot spots". Ambio, 23(3):176-180.

Hagman, D. K. \& Gittings, S. R. 1992. Coral bleaching in high latitude reefs at the Flower Garden Banks, NW Gulf of Mexico. In: INTERNATIONAL CORAL REEF SYMPOSIUM, 7. Guam, 1992. Proceedings. Guam, 1:38-43.

Laborel, J. 1970. Les Peuplements de Madreporaires des Cotes Tropicales du Brésil. Ann. Univ. Abidjan, ser. E, Ecologie, 2:1-261. 
Leão, Z. M. A. N.; Araujo, T. M. F. \& Nolasco, M. C. 1988. The coral reefs off the coast of eastern Brazil. In: INTERNATIONAL CORAL REEF SYMPOSIUM, 6. Townsville, 1988. Proceedings. Townsville, 3:339-347.

Migotto, A. E. 1997. Anthozoan bleaching on the southeastern coast of Brazil in the summer of 1994. In: INTERNATIONAL CONFERENCE ON COELENTERATE BIOLOGY, 6. Leeuwenhorst, $1995 . \quad$ Proceedings. Leeuwenhorst, ICCB. p. 329-335.
Reynolds, R. W. \& Smith, T. M. 1994. Improved global sea surface temperature analyses using optimum interpolation. J. Climate, 7(6):929-948.

Ware, J. R.; Fautin, D. G. \& Buddemeier, R. W. 1996. Patterns of coral bleaching: modeling the adaptive bleaching hypothesis. Ecol. Model., 84(1/3):199-214.

(Manuscript received 26 March 1998; revised 24 August 1998; accepted 11 March 1999) 